RYSZARD DACHOWSKI

KATARZYNA KOMISARCZYK

Kielce University of Technology

KAMILA KOMISARCZYK

Uniwersytet Jana Kochanowskiego w Kielcach

e-mail: komisarczyk.kasia@gmail.com
Manuscript submitted 2018.07.09 - revised 2018.07.30 initially accepted for publication 2018.08.02, published in September 2018

\title{
ANALYSIS OF THE INFLUENCE OF FACTORS INCREASING THE CHARACTERISTICS OF AUTOCLAVED PRODUCTS USING THE DEMATEL METHOD
}

\section{ANALIZA WPŁYWU CZYNNIKÓW KSZTAŁTUJĄCYCH CECHY TWORZYW AUTOKLAWIZOWANYCH PRZY UŻYCIU METODY DEMATEL}

DOI: $10.30540 /$ sae-2018-023

\begin{abstract}
Sand-lime products are characterized by advantageous features: compressive strength, thermal accumulation and acoustic insulation. Product features are resultative choice of decisions made at individual stages of the production process: method of thickening the raw material mixture, time and temperature of autoclaving and the pressure of saturated steam. The above factors may affect on the characteristics of sand-lime products not only directly, but also through other factors. However, there is no suggestion in the literature about the relationship between these factors. The aim of this article is to find answers to the following questions: which stage of the technological process is the most important? What impact does the individual stages have on each other? Whether and to what extent modification of a given stage will affect the compressive strength of finished products? The authors carried out an analysis using the DEMATEL method to identify factors that have a key influence on autoclaved materials. The results show that using the right amount of water in the raw material mixture is the most important factor. To a slightly lesser extent, proper selection of amount of the quick lime is important. The least important factor is the method of forming silicate products. Although the time of autoclaving has a large contribution in the creation of the impact network, however it is caused by the influence of thermal and humidity conditions, the amount of lime, water and, in the low extent, the molding method.
\end{abstract}

Keywords: DEMATEL method, autoclaved materials, production technology

\section{Streszczenie}

Wyroby wapienno-piaskowe charakteryzuja się korzystnymi cechami użytkowymi: wytrzymałościa na ściskanie, akumulacja cieplna oraz izolacyjnościa akustyczna. Cechy wyrobów stanowiq pochodna wyboru decyzji podejmowanych na poszczególnych etapach procesu produkcji: sposobu zagęszczania mieszanki surowcowej, czasu i temperatury autoklawizacji oraz ciśnienia nasyconej pary wodnej. Powyższe czynniki moga oddziatywać na cechy wyrobów wapienno-piaskowych nie tylko bezpośrednio, lecz także za pośrednictwem pozostalych czynników. Jednak w literaturze brak jest sugestii dotyczacych zależności pomiędzy tymi czynnikami. Celem artykułu jest znalezienie odpowiedzi na pytania: który z etapów procesu technologicznego jest najważniejszy? Jaki wpływ poszczególne etapy wywieraja na siebie? Czy i w jakim stopniu modyfikacja danego etapu wplynie na wytrzymatość na ściskanie gotowych wyrobów? Autorzy przeprowadzili analize $z$ wykorzystaniem metody DEMATEL w celu wskazania czynników majacych kluczowy wpływ na autoklawizowane materiały. Wyniki pokazuja, że zastosowanie odpowiedniej ilości wody w mieszaninie surowcowej jest najistotniejszym czynnikiem. W niewiele mniejszym stopniu ważny jest właściwy dobór ilościowy wapna palonego. Najmniej ważnym czynnikiem 
jest sposób formowania wyrobów silikatowych. Wprawdzie czas autoklawizacji ma duży udział w tworzeniu sieci wplywu, jednak jest to spowodowane wplywem warunków cieplno-wilgotnościowych, ilościa wapna, wody i w najmniejszym stopniu sposobem formowania.

Slowa kluczowe: metoda DEMATEL, tworzywa autoklawizowane, technologia produkcji

\section{INTRODUCTION}

In the domestic silicate industry, sand-lime bricks with a compression strength class of $20 \mathrm{MPa}$ or $25 \mathrm{MPa}$ are obtained. Although, there is a demand for lime-sand products with strength characteristics corresponding to class 35 and higher, on the building materials market. The improvement of these features can be achieved in several ways. However, they are a function of many factors, both physical (physical properties of quartz sand, conditions and method of forming products) as well as chemical factors (chemical composition of aggregate and binder, molar ratio $\mathrm{CaO} / \mathrm{SiO}_{2}$, conditions of hydrothermal treatment - pressure and curing time) $[5,12]$. The microstructure of sand-lime products, so the mineral composition, the morphology of the synthesis products (hydrated calcium silicates) and porosity, is the main factor determining the strength characteristics of finished products. In the article, the authors have attempted to investigate causal relationships between technological factors affecting the utilitarian parameters of silicates. The aim of this article is to find answers to the following questions: which stage of the technological process is the most important? What impact does the individual stages have on each other? Whether and to what extent modification of a given stage will affect the compressive strength of finished products?

\section{RESEARCH METHODOLOGY}

\subsection{Technological factors}

The selection of technological process factors was made on the basis of experimental research and literature review. The following factors were analyzed in the work:

C1-autoclaving time. Appropriately changing time of hydrothermal treatment with the appropriate range of water vapor pressure and temperature leads to the desired compressive strengths of finished products. For each water vapor pressure value, the temperature during hydrothermal treatment is known. Ensuring the right time during the autoclaving process affects on putting in order the structure of the C-S-H (I) phase and its transformation into tobermorite. In turn, the tobermorite may be transformed into a higher phase, ksonotlitium or other [13, 14]. The researchers claim that the excessive extension of the

\section{WPROWADZENIE}

W warunkach krajowego przemysłu silikatowego otrzymuje się cegły wapienno-piaskowe o klasie wytrzymałości na ściskanie równej $20 \mathrm{MPa}$ lub $25 \mathrm{MPa}$. $\mathrm{Na}$ rynku materiałów budowlanych istnieje jednak zapotrzebowanie na wyroby wapienno-piaskowe o cechach wytrzymałościowych odpowiadających klasie 35 i wyższej. Poprawę owych cech można osiągnąć na kilka sposobów. Są one jednak funkcją wielu czynników, zarówno fizycznych (właściwości fizyczne piasku kwarcowego, warunki i sposób formowania wyrobów), jak i czynników chemicznych (skład chemiczny kruszywa i spoiwa, stosunek molowy $\mathrm{CaO} / \mathrm{SiO}_{2}$, warunki obróbki hydrotermalnej - ciśnienie i czas utwardzania) $[5,12]$. Mikrostruktura tworzyw wapienno-piaskowych, czyli skład mineralny, morfologia produktów syntezy (uwodnione krzemiany wapnia) oraz porowatość, jest głównym czynnikiem determinującym cechy wytrzymałościowe gotowych wyrobów. W artykule autorzy podjęli próbę zbadania związków przyczynowo-skutkowych między czynnikami technologicznymi wpływającymi na parametry użytkowe silikatów. Celem artykułu jest znalezienie odpowiedzi na pytania: który z etapów procesu technologicznego jest najważniejszy? Jaki wpływ poszczególne etapy wywierają na siebie? Czy i w jakim stopniu modyfikacja danego etapu wpłynie na wytrzymałość na ściskanie gotowych wyrobów?

\section{METODOLOGIA BADAŃ}

\subsection{Czynniki technologiczne}

Selekcji czynników procesu technologicznego dokonano na podstawie badań doświadczalnych i przeglądu literatury. W pracy przeanalizowano następujące czynniki:

C1 - czas autoklawizacji. Odpowiednio zmieniający się czas obróbki hydrotermalnej przy odpowiednio stosowanym zakresie ciśnień pary wodnej i temperatury prowadzi do uzyskania zamierzonych wytrzymałości na ściskanie gotowych wyrobów. Dla każdej wartości ciśnienia pary wodnej znana jest temperatura podczas obróbki hydrotermalnej. Zapewnienie właściwego czasu w trakcie procesu autoklawizacji wpływa na porządkowanie struktury fazy C-S-H(I) i przekształcenie się jej w tobermoryt. Z kolei tobermoryt może ulegać przekształceniu w fazę wyższą, ksonotlit lub inne [13, 14]. Naukowcy twierdzą, że nadmierne wydłużenie 
hardening time of silicate products may, however, affect the compression strength of autoclaved products, which is probably related to structural changes [10].

C2 - thermal and humid conditions. The autoclaving process is usually accompanied by a temperature of $150 \div 200^{\circ} \mathrm{C}$ and water vapor pressure of equivalent values, adequate to the given temperature range, ie $0.8 \div 1.6 \mathrm{MPa}$. In a few silicates factories, especially in Western Europe, the applied pressure is from 0.8 MPa to even 2.5 MPa. During the hydrothermal treatment, the solubility of quartz increases several times, which determines the reaction speed between silica and calcium hydroxide, forming in result of the hydration of burnt lime [11]. During the process proceeded in the autoclave, hydrated calcium silicates are formed with different chemical compositions and different internal structure arrangement [7]. The reaction products of calcium ions with silica have a very positive affect on the utilitarian properties of finished sand-lime products, i.e. compressive strength, low water absorption and good frost resistance.

C3 - pressing. Traditionally, the sand-lime brick is pressed at a pressure of about $15 \div 20 \mathrm{MPa}$. The pressure value should be high enough to ensure an adequate degree of compaction of the raw material mixture, which has no plastic properties. The researchers, in their works use different variants: two-stage pressing with interstage de-aeration at a pressure of $10 \mathrm{MPa}$ and $20 \mathrm{MPa}$ [9], singlestage pressing with a pressure of $25.5 \mathrm{MPa}$ [3]. A significant increase in pressure may, however, lead to the cracking of sand grains, which in turn will reduce the compressive strength of finished products.

C4 - application of vibropressing. This method is used, among others, for compacting concrete pavement slabs [15], paving stones [8], masonry bricks [1], etc. Based on research carried out by scientists, we can conclude that the use of vibropressing in sand-lime products has a more beneficial effect on the compressive strength of the finished product than pressing. It gives a result of a higher degree of compaction, which translates into a reduction in porosity.

C5-Amount of lime. Lime is a substance that bonds individual grains of quartz sand. The consumption of lime in the range of $4 \div 12 \% \mathrm{CaO}$ in the raw material mixture is directly proportional to the compressive strength of finished products. In order to obtain the best physical parameters of finished products, the czasu hartowania wyrobów silikatowych może jednak wpłynąć na obniżenie wytrzymałości na ściskanie autoklawizowanych wyrobów, co prawdopodobnie związane jest ze zmianami strukturalnymi [10].

C2 - warunki cieplno-wilgotnościowe. Procesowi autoklawizacji towarzyszy zwykle temperatura $150 \div 200^{\circ} \mathrm{C}$ oraz ciśnienie pary wodnej o wartościach równoważnych, adekwatnych do podanego zakresu temperatur, tj. 0,8 $\div 1,6 \mathrm{MPa}$. W niewielu zakładach produkcji silikatów, zwłaszcza na zachodzie Europy, stosuje się ciśnienie od 0,8 $\mathrm{MPa}$ do nawet 2,5 $\mathrm{MPa}$. W czasie obróbki hydrotermalnej kilkakrotnie wzrasta rozpuszczalność kwarcu, co determinuje prędkość reakcji pomiędzy krzemionką a wodorotlenkiem wapnia powstającym w wyniku hydratacji wapna palonego [11]. W trakcie procesu przebiegającego w autoklawie dochodzi do utworzenia uwodnionych krzemianów wapnia, o zróżnicowanym składzie chemicznym i różnym uporządkowaniu struktury wewnętrznej [7]. Produkty reakcji jonów wapnia z krzemionką wpływają bardzo korzystnie na cechy użytkowe gotowych wyrobów wapienno-piaskowych, tj. wytrzymałość na ściskanie, niską nasiąkliwość i dobrą mrozoodporność. C3 - prasowanie. Tradycyjnie cegłę wapienno-piaskową prasuje się pod ciśnieniem ok. $15 \div 20 \mathrm{MPa}$. Wartość ciśnienia powinna być na tyle duża, aby zapewniała odpowiedni stopień zagęszczenia mieszaniny surowcowej, nie wykazującej właściwości plastycznych. Badacze w swoich pracach wykorzystują różne warianty: prasowanie dwustopniowe i dwuetapowe z międzystopniowym odpowietrzeniem przy wartości ciśnienia $10 \mathrm{MPa}$ i $20 \mathrm{MPa}$ [9], prasowanie jednostopniowe o wartości ciśnienia 25,5 MPa [3]. Znaczny wzrost wartości ciśnienia może jednak doprowadzić do pękania ziaren piasku, co w konsekwencji wpłynie na obniżenie wytrzymałości na ściskanie gotowych wyrobów. C4 - zastosowanie wibroprasowania. Metoda wykorzystywana między innymi do zagęszczania betonowych płyt chodnikowych [15], kostki brukowej [8], cegieł murarskich [1] itd. Na podstawie badań przeprowadzonych przez naukowców można wnioskować, że zastosowanie wibroprasowania $\mathrm{w}$ wyrobach wapienno-piaskowych ma korzystniejszy wpływ na wytrzymałość na ściskanie gotowego wyrobu niż prasowanie. Uzyskuje się dzięki temu większy stopień zagęszczenia, co przekłada się na zmniejszenie porowatości.

C5 - Ilość wapna. Wapno jest substancją spajającą poszczególne ziarna piasku kwarcowego. Zużycie wapna zawierającego się w granicach $4 \div 12 \% \mathrm{CaO}$ $\mathrm{w}$ mieszaninie surowcowej jest wprost proporcjonalne do wytrzymałości na ściskanie gotowych wy- 
$\mathrm{CaO} / \mathrm{SiO}_{2}$ molar ratio should stand at 0.09 . In the production process, lime plays an important role both at the stage of forming products (it fulfills the function of plasticizer) and during the hardening process. For it is a source of calcium ions, which after passing to the high $\mathrm{pH}$ liquid phase react with silicate ions. As a result of the occurring synthesis, mainly amorphous $\mathrm{C}-\mathrm{S}-\mathrm{H}$ phase and crystalline tobermorite $\left(\mathrm{C}_{5} \mathrm{~S}_{6} \mathrm{H}_{5}\right)$ are formed $[9,10]$. It should be noted that in addition to the quantitative share of quicklime in the mixture, the quality factor (value of active $\mathrm{CaO}$, lime activity, fragmentation) is equally important.

C6 - the amount of water. Water is essential for complete hydration of $\mathrm{CaO}$ and $\mathrm{MgO}$ contained in burnt lime. It ensures the appropriate rheological properties of the raw material mass, which guarantees proper forming of products. The amount of water added to the mixture depends on the sand grain composition and the lime content. The water should be used in amounts ensuring humidity of the mixture at the level of $4 \div 8 \%$. Using too much water in the mixture causes the samples to expand and crack [16]. Water is also used during hydrothermal treatment, to produce a sufficient amount of water vapor in an autoclave.

\subsection{Multi-attribute analysis of decisions}

Among the multi-attribute analysis methods, the most popular are: AHP, ANP, DEMATEL, REMBRANT. The DEMATEL method was used for the study, giving the opportunity to study phenomena through cause and effect analysis. The calculation algorithm in the DEMATEL method was divided into five stages.

\section{Stage 1}

Development of a cause-and-effect graph.

\section{Stage 2}

Creation of a direct impact matrix (matrix A). In the square matrix $\mathrm{n} \times \mathrm{n}$ individual lines are dedicated to the factors appearing in the comparisons first, while the columns are dedicated to the factors that appear in the comparisons as the second [2]. The direct impact matrix is not a symmetric matrix. Intensity of the influence of individual factors on other factors can be expressed on a scale of $0 \div 4$. For the identical relation of the influence of factors, the given word of matrix A assumes the value 0 . robów. W celu uzyskania najlepszych parametrów fizycznych gotowych wyrobów stosunek molowy $\mathrm{CaO} / \mathrm{SiO}_{2}$ powinien wynosić 0,09 . W procesie produkcji wapno pełni istotną rolę zarówno na etapie formowania wyrobów (spełnia funkcję plastyfikatora), jak i podczas procesu hartowania. Jest bowiem źródłem jonów wapnia, które po przejściu do fazy ciekłej o wysokim $\mathrm{pH}$ reagują $\mathrm{z}$ jonami krzemianowymi. W wyniku zachodzącej syntezy powstaje głównie amorficzna faza C-S-H oraz krystaliczny tobermoryt $\left(\mathrm{C}_{5} \mathrm{~S}_{6} \mathrm{H}_{5}\right)[9,10]$. Należy zwrócić uwagę, że oprócz ilościowego udziału wapna palonego w mieszaninie, równie ważnym jest czynnik jakościowy (wartość aktywnego $\mathrm{CaO}$, aktywność wapna, rozdrobnienie).

C6 - ilość wody. Woda jest niezbędna do całkowitej hydratacji $\mathrm{CaO}$ i $\mathrm{MgO}$ zawartych w wapnie palonym. Zapewnia odpowiednie właściwości reologiczne masie surowcowej, co gwarantuje właściwe formowanie wyrobów. Ilość wody dodawanej do mieszaniny zależna jest od składu ziarnowego piasku i zawartości wapna. Wodę powinno stosować się w ilościach zapewniających wilgotność mieszanki na poziomie $4 \div 8 \%$. Zastosowanie zbyt dużej ilości wody w mieszaninie powoduje rozprężanie się próbek i ich pękanie [16]. Woda wykorzystywana jest również podczas obróbki hydrotermalnej do wytworzenia odpowiedniej ilości pary wodnej w autoklawie.

\subsection{Wieloatrybutowa analiza decyzj}

Spośród metod wieloatrybutowej analizy najbardziej popularnymi są: AHP, ANP, DEMATEL, REMBRANT. Do badań została zastosowana metoda DEMATEL, dająca możliwość badania zjawisk poprzez analizę przyczynowo-skutkową.

Algorytm obliczeń w metodzie DEMATEL podzielono na pięć etapów.

\section{Etap 1}

Opracowanie grafu przyczynowo-skutkowego.

\section{Etap 2}

Utworzenie macierzy bezpośredniego wpływu (macierz A). W macierzy kwadratowej n x n poszczególne wiersze są dedykowane czynnikom występujących w porównaniach jako pierwsze, natomiast kolumny są dedykowane czynnikom, które występują w porównaniach jako drugie [2]. Macierz bezpośredniego wpływu nie jest macierzą symetryczną. Intensywność wpływu poszczególnych czynników na inne czynniki można wyrazić oceną w skali $0 \div 4$. Dla tożsamych relacji wpływu czynników dany wyraz macierzy A przyjmuje wartość 0 . 


\section{Stage 3}

Normalization of matrix A according to the formula:

$$
B N=\frac{1}{\lambda} A
$$

wherein:

$$
\lambda=\max \left(\max _{j} \sum_{i=1}^{n} a_{i j}: \max _{i} \sum_{i=1}^{n} a_{i j}\right),
$$

where: $i$ - line number, $j$ - column number.

\section{Stage 4}

Creation of a total impact matrix (matrix T) [6]

$$
T=B N+P
$$

where:

$$
P=B N^{2}(I-B N)^{-1}
$$

$I=$ unit matrix.

\section{Stage 5}

Determination of $\mathrm{Z}$ significance indicators and $\mathrm{R}$ relationship indicators [4]

$$
Z=\sum_{j=1}^{n} t_{i j}+\sum_{j=1}^{n} t_{j i} \quad R=\sum_{j=1}^{n} t_{i j}-\sum_{j=1}^{n} t_{j i}
$$

\section{RESEARCH RESULTS}

Participants in the construction investment process took part in the survey. Each expert determined the impact strength of factors on a scale of $0 \div 4(0-$ no impact, 1 - very low impact, 2 - low impact, 3 - high impact, 4 - very high impact). Based on this, 6 partial direct impact matrices were created, counting the dominants:

\section{Etap 3}

Znormalizowanie macierzy A zgodnie ze wzorem:

$$
B N=\frac{1}{\lambda} A
$$

przy czym:

$$
\lambda=\max \left(\max _{j} \sum_{i=1}^{n} a_{i j}: \max _{i} \sum_{i=1}^{n} a_{i j}\right),
$$

gdzie: $i$ - numer wiersza, $j$ - numer kolumny.

\section{Etap 4}

Utworzenie macierzy całkowitego wpływu (macierz T) [6]

$$
T=B N+P
$$

gdzie:

$$
P=B N^{2}(I-B N)^{-1}
$$

$I=$ mecierz jednostkowa.

\section{Etap 5}

Wyznaczenie wskaźników znaczenia Z i wskaźników relacji R [4]

$$
Z=\sum_{j=1}^{n} t_{i j}+\sum_{j=1}^{n} t_{j i} \quad R=\sum_{j=1}^{n} t_{i j}-\sum_{j=1}^{n} t_{j i}
$$

\section{REZULTATY BADAŃ}

W badaniu udział wzięli uczestnicy procesu inwestycyjnego budowlanego. Każdy ekspert określił siłę wpływu czynników w skali $0 \div 4$ ( 0 - brak wpływu, 1 - bardzo niski wpływ, 2 - niski wpływ, 3 - wysoki wpływ, 4 - bardzo duży wpływ). Na tej podstawie stworzono sześć cząstkowych macierzy bezpośredniego wpływu, licząc dominanty:

$$
A=\left[\begin{array}{llllll}
0 & 3 & 0 & 0 & 1 & 0 \\
4 & 0 & 0 & 0 & 2 & 1 \\
0 & 0 & 0 & 0 & 0 & 1 \\
0 & 0 & 0 & 0 & 0 & 1 \\
3 & 0 & 2 & 2 & 0 & 3 \\
0 & 4 & 4 & 4 & 3 & 0
\end{array}\right]
$$

Relationships between individual factors have been assigned numerical assessments. The line styles express the influence of particular factors on other factors. The solid line indicates the effect of $\mathrm{C} 1$, the dashed line impact $\mathrm{C} 2$, the wave-shaped line impact $\mathrm{C} 3$, the line with the system: dash-dot-dash influence C4, line with signs , X" C5 influence and line in the zigzag shape impact $\mathrm{C} 6$.
Relacjom między poszczególnymi czynnikami zostały przypisane oceny w postaci liczbowej. Kroje linii wyrażają wpływ poszczególnych czynników na pozostałe czynniki. Linia ciągła oznacza wpływ $\mathrm{C}$ 1, linia przerywana wpływ $\mathrm{C} 2$, linia w kształcie fali wpływ C3, linia o układzie: kreska-kropka-kreska wpływ C4, linia ze znakami „X” wpływ C5 oraz linia w kształcie zygzakowatym wpływ C6. 


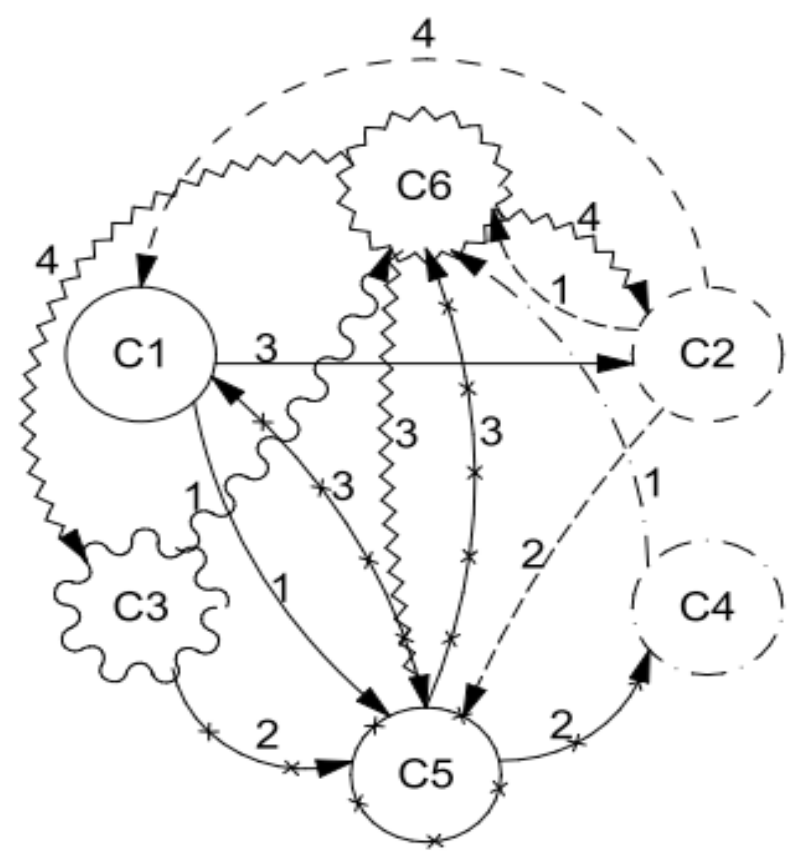

Sixth row of the matrix A is characterized by the largest value, while rows 3 and 4 are the smallest value of the sum of elements. The direct impact matrix A has been subjected to normalization:
Fig. 1. Cause and effect graph Rys. 1. Graf przyczynowo-skutkowy

Wiersz szósty macierzy A charakteryzuje się największą, a wiersze 3 i 4 najmniejszą wartością sumy elementów. Macierz bezpośredniego wpływu A poddano normowaniu:

$$
B N=\left[\begin{array}{cccccc}
0 & 0,2 & 0 & 0 & 0,0667 & 0 \\
0,2667 & 0 & 0 & 0 & 0,1333 & 0,0667 \\
0 & 0 & 0 & 0 & 0 & 0,0667 \\
0 & 0 & 0 & 0 & 0 & 0,0667 \\
0,2 & 0 & 0,1333 & 0,1333 & 0 & 0,2 \\
0 & 0,2667 & 0,2667 & 0,2667 & 0,2 & 0
\end{array}\right]
$$

On the basis of the direct influence matrix, the Na podstawie macierzy wpływu bezpośredniego indirect influence matrix $P$ was calculated: wyliczono macierz wpływu pośredniego P:

$$
P=\left[\begin{array}{lllllll}
0,0828 & 0,0274 & 0,0256 & 0,0256 & 0,044 & 0,0407 \\
0,0646 & 0,0981 & 0,0575 & 0,0575 & 0,059 & 0,0527 \\
0,0095 & 0,0219 & 0,0224 & 0,0224 & 0,0185 & 0,0081 \\
0,0095 & 0,0219 & 0,0224 & 0,0224 & 0,0185 & 0,0081 \\
0,0477 & 0,1169 & 0,0784 & 0,0784 & 0,0826 & 0,0525 \\
0,143 & 0,0612 & 0,0696 & 0,0696 & 0,0777 & 0,1222
\end{array}\right]
$$

and the matrix of total affect $\mathrm{T}$ :

oraz macierz wpływu całkowitego T:

$$
T=\left[\begin{array}{llllllll}
0,0828 & 0,2274 & 0,0256 & 0,0256 & 0,1106 & 0,0407 \\
0,3313 & 0,0981 & 0,0575 & 0,0575 & 0,1924 & 0,1193 \\
0,0095 & 0,0219 & 0,0224 & 0,0224 & 0,0185 & 0,0748 \\
0,0095 & 0,0219 & 0,0224 & 0,0224 & 0,0185 & 0,0748 \\
0,2477 & 0,1169 & 0,2117 & 0,2117 & 0,0826 & 0,2525 \\
0,143 & 0,3279 & 0,3363 & 0,3363 & 0,2777 & 0,1222
\end{array}\right]
$$


The obtained $\mathrm{P}$ matrix defines only indirect influences, therefore the values in the $\mathrm{P}$ and $\mathrm{T}$ matrices are the same wherever in the $\mathrm{BN}$ matrix there are zeros. The values of the matrix $\mathrm{T}$ indicate the degree of influence of factors on themselves and on other factors, taking into account both direct influences and indirect influences [4, 17]. From here, it can be seen that all impact values have increased. Some even to a fairly large extent. The effect of $\mathrm{C} 6$ on $\mathrm{C} 1$ increased from 0 to 0.143 . This is due to the fact that C6 has a very high impact on C2 (at 0.3279). C2, on the other hand, has a large impact on $\mathrm{C} 5$, which consequently gives a high indirect impact on $\mathrm{C} 1$. In turn, the impact of $\mathrm{C} 5$ on $\mathrm{C} 2$ increased from 0 to 0.1169 . The reason for this is the high impact of C5 on C6 (0.2525), and C6 strongly affects $\mathrm{C} 2$, which causes a large indirect influence of $\mathrm{C} 5$ on $\mathrm{C} 2$.

$\mathrm{Z}$ indexes and ratios of $\mathrm{R}$ relations were determined:

$$
Z:=\left[\begin{array}{l}
1,3365 \\
1,6700 \\
0,8455 \\
0,8455 \\
1,8234 \\
2,2278
\end{array}\right]
$$

On the basis of the obtained results, the thermalhumid conditions (C2), the amount of lime (C5) and the amount of water (C6) have positive values of the relation ratio. This means that their impact on other factors is stronger than the impact of others on them. The amount of water (C6) has a very high value of the indicator of meaning and relation. It results from the fact that it has a large share in the creation of the impact network (meaning indicator) and that this participation is primarily based on the impact on other factors (large, positive value of the indicator of relations). The obtained results also indicate that pressing (C3) and vibropressing $(\mathrm{C} 4)$, and to a lesser extent also the time of autoclaving $(\mathrm{C} 1)$ remain under the clear influence of other factors. At the same time, they have little influence on other factors. Dependencies between indicators of significance and relations are presented in the graph shown in Figure 2.
Uzyskana macierz P określa tylko wpływy pośrednie, dlatego wartości w macierzy P i T są takie same wszędzie tam, gdzie w macierzy BN są zera. Wartości macierzy T wskazują stopień wpływu czynników na siebie i na inne czynniki, uwzględniający zarówno wpływy bezpośrednie, jak i wpływy pośrednie $[4,17]$. Stąd można zauważyć, że wszystkie wartości wpływu uległy zwiększeniu. Niektóre nawet w dość znacznym zakresie. Wpływ C6 na C1 zwiększył się z 0 do 0,143 . Wynika to z faktu, że C6 ma bardzo wysoki wpływ na C2 (na poziomie 0,3279 ). C2 ma natomiast duży wpływ na $\mathrm{C} 5$, co w konsekwencji daje duży wpływ pośredni na $\mathrm{C} 1$. Z kolei wpływ C5 na C2 zwiększył się z 0 do 0,1169. Przyczyną jest tutaj duży wpływ C5 na C6 $(0,2525)$, a C6 bardzo mocno wpływa na $\mathrm{C} 2$, co powoduje duży pośredni wpływ C5 na C2.

Wyznaczono wskaźniki znaczenia Z i wskaźniki relacji R:

$$
R=\left[\begin{array}{c}
-0,3110 \\
0,0421 \\
-0,5063 \\
-0,5063 \\
0,4228 \\
0,8589
\end{array}\right]
$$

Na podstawie uzyskanych wyników warunki cieplno-wilgotnościowe (C2), ilość wapna (C5) i ilość wody (C6) mają dodatnie wartości wskaźnika relacji. Oznacza to, że ich oddziaływanie na inne czynniki jest silniejsze niż oddziaływanie innych na nie. Ilość wody (C6) ma bardzo dużą wartość wskaźnika znaczenia i relacji. Wynika z tego, że ma duży udział w tworzeniu sieci wpływu (wskaźnik znaczenia) oraz że udział ten polega przede wszystkim na wpływie na inne czynniki (duża, dodatnia wartość wskaźnika relacji). Otrzymane wyniki wskazują również na to, że prasowanie (C3) i wibroprasowanie (C4), a w mniejszej mierze także czas autoklawizacji (C1), pozostają pod wyraźnym wpływem innych czynników. Jednocześnie słabo wpływają one na pozostałe czynniki. Zależności między wskaźnikami znaczenia i relacji przedstawiono na rysunku 2. 


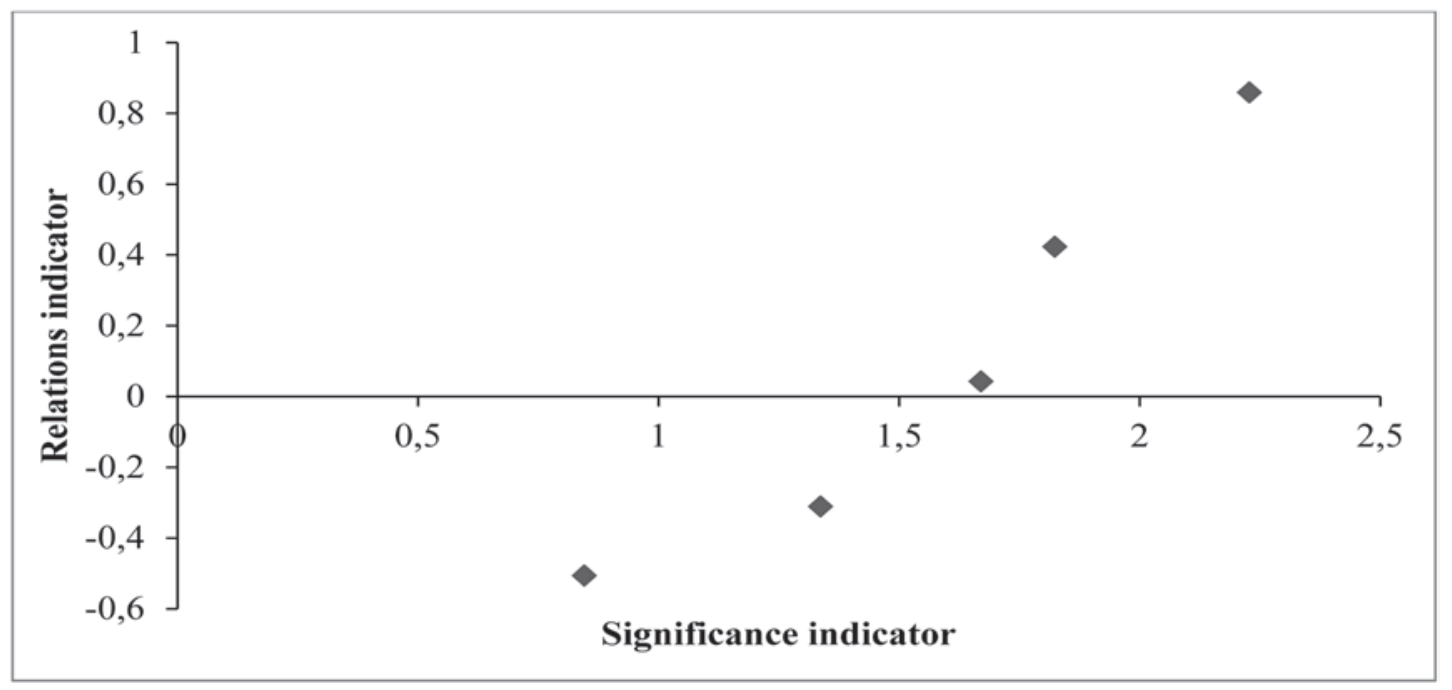

Fig. 2. Graph of the significance and influence of the analyzed variables - final results of the analysis Rys. 2. Wykres znaczenia wplywu badanych zmiennych - ostateczne wyniki analizy

\section{CONCLUSIONS}

The application of the presented method to determine causal relationships between technological factors affecting the utilitarian parameters of silicate products, causes that the decision support process is more objective and does not focus only on the intuition of the decision maker.

Based on the results obtained, it is concluded that:

- applying the right amount of water (C6) in the raw material mixture is the most important factor, because water has a very large share in the creation of the impact network of factors and strongly affects other factors,

- the correct selection of the amount of quick lime is important in a less extent,

- the least important factors were $\mathrm{C} 3$ and $\mathrm{C} 4$, related to the formation of silicate products,

- thermal and humid conditions (C2), the amount of lime (C5) and the amount of water (C6) have a stronger impact on other factors than others on them,

- although the time of autoclaving has a large share in the creation of the impact network, however it is caused by the impact of thermal and humidity conditions, the amount of lime, water and, in a less extent, the forming method.

\section{WNIOSKI}

Zastosowanie przedstawionej metody do określenia związków przyczynowo-skutkowych między czynnikami technologicznymi wpływającymi na parametry użytkowe wyrobów silikatowych powoduje, że proces wspomagania decyzji jest bardziej obiektywny i nie skupia się jedynie na intuicji decydenta.

Na podstawie uzyskanych wyników wnioskuje się, że:

- zastosowanie odpowiedniej ilości wody (C6) w mieszaninie surowcowej stanowi najistotniejszy czynnik, gdyż woda ma bardzo duży udział w tworzeniu sieci wpływu czynników oraz silnie oddziałuje na pozostałe czynniki,

- w niewiele mniejszym stopniu ważny jest właściwy dobór ilościowy wapna palonego,

- najmniej istotnymi okazały się czynniki C3 i C4, związane z formowaniem wyrobów silikatowych,

- warunki cieplno-wilgotnościowe (C2), ilość wapna (C5) i ilość wody (C6) silniej oddziałują na inne czynniki niż inne na nie,

- wprawdzie czas autoklawizacji ma duży udział w tworzeniu sieci wpływu, jednak jest to spowodowane wpływem warunków cieplno-wilgotnościowych, ilością wapna, wody i w najmniejszym stopniu sposobem formowania.

\section{References}

[1] Burciaga-Díaz O., Díaz-Guillén M.R., Fuentes A.F., Escalante-Garcia J.I.: Mortars of alkali-activated blast furnace slag with high aggregate: binder ratios. Construction and Building Materials 44, 2013, 607-614.

[2] Dytczak M., Ginda G., Wojtkiewicz T.: Analiza związków przyczynowo-skutkowych w awarii konstrukcji przy użyciu metody DEMATEL, XXV Konferencja Naukowo- techniczna „Awarie Budowlane 2011”. 419-426. 
[3] Georgiev D., Bogdanov B. i inni: Building material from calcium silicate - preparation and properties Tom 4 International conference on the applications of traditional \& high performance materials in harsh environment.

[4] Hsu, C.-W., Kuo, T.-C., Chen, S.-H., \& Hu, A. H.: Using DEMATEL to develop a carbon management model of supplier selection in green supply chain management. Journal of Cleaner Production 56. 164-172, 2013.

[5] Małolepszy J. i inni: Podstawy technologii materiałów budowlanych i metody badań. Kraków. Wydawnictwo AGH, 2013.

[6] Nermend K.:Metody analizy wielokryterialnej i wielowymiarowej we wspomaganiu decyzji. Warszawa. Wydawnictwo PWN 2017.

[7] Nocuń-Wczelik W.: Struktura i właściwości uwodnionych krzemianów wapniowych. Kraków. Polskie Wydawnictwo Ceramiczne 1999.

[8] Novosad P., Přikryl J., Louda P. i inni: Functional vibro pressed pavement with ecological benefits. Advanced Materials Research 787, 328-332.

[9] Pytel Z.: Wplyw dodatków mineralnych na wlaściwości tworzyw wapienno-piaskowych. Polskie Wydawnictwo Ceramiczne, Kraków 2016.

[10] Pytel Z.: Modyfikowanie składu fazowego i mikrostruktury autoklawizowanych tworzyw wapienno-piaskowych. Kraków. Polskie Wydawnictwo Ceramiczne, Kraków 2014.

[11] Rademaker P.D., Reiman V.: Autoclaving silicate bricks. Zement-Kalk-Gips, 1994.

[12] Sastry B. S. R.: Investigations on Sand Lime Bricks-Part I. Transactions - Indian Ceramic Society 10 (1): 62-67, 2014.

[13] Stępień A.: The impact of glass additives on the functional and microstructural properties of sand-lime bricks. International Journal of Civil and Environmental Engineering 4 (3), 2017.

[14] Stępień A., Kostrzewa P.: Autoclaved sand-lime products with a Polypropylene Mesh. Materials Science and Engineering. 245, 2017.

[15] Suleymanova L. A., Kara K. A. i inni: The influence of technological factors on the basic Properties vibressed conrete paving slabs. Research Journal of Applied Sciences 9 (11): 874-878, 2014.

[16] Walker R. C., Purton M. J.: Some observations on calcium silicate brick specimens in the autoclave. Journal of Applied Chemistry and Biotechnology. 23 (12): 879-886, 2007.

[17] Wu, H.-H., \& Chang, S.-Y.: A case study of using DEMATEL method to identify critical factors in green supply chain management. Applied Mathematics and Computation. 256. 394-403, 2015.

\section{Acknowledgments:}

The work was financed by Kielce University of Technology, part of the statutory work No. 02.0.05.00/2.01.01.01.0002 MNSP.BKTO.17.002

\section{Podziękowania:}

Praca byta finansowana przez Politechnikę Świętokrzyska, wramach pracystatutowej nr: 02.0.05.00/2.01.01.01.0002 MNSP.BKTO.17.002 